\title{
MENYINGKAP BUDAYA PENYEBAB FRAUD: STUDI ETNOGRAFI DI BADAN USAHA MILIK NEGARA
}

\author{
Ruri Octari Dinata, Gugus Irianto, \& Aji Dedi Mulawarman \\ Fakultas Ekonomi dan Bisnis, Universitas Brawijaya, Indonesia \\ Email: ruryoctarii@gmail.com
}

\begin{abstract}
Abstrak: Menyingkap Budaya Penyebab Fraud: Studi Etnografi di Badan Usaha Milik Negara. Penelitian ini bertujuan untuk menyingkap budaya penyebab fraud di BUMN dengan studi etnografi sebagai metodologi penelitiannya. Data diperoleh dari observasi langsung ke situs penelitian di BUMN X yang terletak di Kota Medan Sumatera Utara dan melakukan wawancara dengan informan di situs penelitian tersebut. Hasil penelitian menunjukkan adanya budaya "semua bisa diatur" serta budaya "prosedur hanya formalitas" yang akhirnya dapat menjadi pemicu terjadinya fraud.
\end{abstract}

Kata kunci: fraud, BUMN, etnografi, budaya semua bisa diatur, budaya prosedur hanya formalitas

\begin{abstract}
Revealing Cultural Causes of Fraud: An Ethnographic Study in Public Company. This ethnographic study aimed to reveal the cultural causes of fraud in public company. The data was obtained from direct observation and interview to the research site at Public Company X, located in Medan City of North Sumatra. This study found that existence of a culture of "all can be arranged" as well as a culture of "procedure only formality" can ultimately lead to fraud.
\end{abstract}

Keywords: fraud, public company, ethnography, culture of all can be arranged, culture of procedure only formality.

\section{PENDAHULUAN}

"There is no such thing as a small fraudit is a large fraud in the process of growing up" (Johnson, 1999:20).

Memang tidak dapat dipungkiri bahwa fraud adalah suatu perbuatan yang tidak etis bahkan dianggap sangat buruk karena dapat memberikan dampak negatif tidak hanya bagi satu individu namun juga bagi suatu organisasi atau lingkungan di mana fraud tersebut dilakukan. Permasalahannya adalah, tidak semua orang menganggap fraud merupakan tindakan buruk yang seharusnya tidak dilakukan. Banyak pelaku fraud beranggapan bahwa tindakan mereka adalah tindakan yang sah-sah saja dilakukan karena hal tersebut merupakan hal yang wajar.

Pendapat Johnson (1999) memberikan satu pandangan mengenai kebiasaan fraud ini. Bahwa setiap jenis fraud yang terlihat kecil sebenarnya merupakan fraud besar yang sedang dalam proses tumbuh. Secara teoretis, kecurangan atau yang lebih dikenal dengan istilah fraud merupakan suatu tindakan yang dianggap "gelap" atau tidak sah dan biasanya dilakukan oleh sekelompok orang atau individu di mana tindakan ini merupakan tindakan yang dilakukan dengan sengaja dan memiliki tujuan untuk memberikan keuntungan bagi dirinya ataupun kelompok itu sendiri. Fraud kerapkali terjadi di suatu entitas atau 
organisasi, mulai dari entitas kecil hingga entitas dengan skala besar. Fraud tidak hanya terjadi dalam batasan satu kelompok saja, bahkan telah mengakar dan menjalar sehingga sangat sulit untuk dikendalikan. Selain itu, fraud juga merupakan suatu tindakan yang tersembunyi sehingga tidak mudah untuk diungkapkan. Hal ini dijelaskan dalam fenomena iceberg di mana fraud yang terjadi pada umumnya meskipun terungkap, yang terlihat di permukaan hanya sebagian kecil saja, selebihnya masih tersembunyi di balik permukaan tersebut. Untuk mengatasi fraud, diperlukan upaya pencegahan dan pendeteksian agar dapat meninimalisir fraud yang terjadi. Namun, upaya untuk mengatasi fraud dengan melakukan pencegahan dan pendeteksian akan menjadi percuma jika dalam menerapkan upaya ini tidak diketahui akar masalah atau penyebab terjadinya fraud. Maka, dalam upaya untuk mencegah dan mendeteksi fraud, hal pertama yang perlu dilakukan adalah mencari tahu apa yang sebenarnya menjadi pemicu terjadinya fraud agar kemudian fraud dapat diatasi.

Sangat miris mengetahui bahwa fraud yang terjadi tidak terlepas dari faktor budaya. Fraud seringkali terjadi karena budaya yang terbentuk atas kebiasaan-kebiasaan individu atau kelompok di dalam suatu organisasi perusahaan. Hal ini dibuktikan dengan hasil penelitian Syahrina (2016) bahwa fraud dapat terjadi karena dua faktor budaya, yaitu budaya cari untung dan budaya cari aman. Kondisi ini menjadi salah satu gambaran bahwa munculnya fraud dapat terjadi karena kebiasaan yang dilakukan di dalam kegiatankegiatan perusahaan. Misalnya seperti kebiasaan mengelompok, senioritas, kebiasaan berdamai dengan sistem, dan lain sebagainya. Kebiasaan yang dilakukan oleh pegawai ini tanpa disadari menjadi alasan mengapa fraud dapat terjadi.

Kasus-kasus mengenai fraud selalu menjadi perhatian publik hingga saat ini. Contohnya saja kasus mengenai Enron yang tidak akan pernah terlepas dari ingatan, atau kasus lainnya seperti WorldCom, American Insurance Group, Lehman Brothers, atau Satyam (Tuanakotta, 2013). Di Indonesia sendiri, kasus mengenai fraud marak sekali terjadi di sektor pemerintahan, di mana temuan-temuan dari penelitian yang telah dilakukan dan berita-berita yang beredar menyimpulkan bahwa terdapat banyak kasus fraud yang dilakukan oleh pegawai maupun pejabat pemerintahan.

Selanjutnya, dikutip dalam laman Indonesian Corruption Watch (ICW, 2016), selama tahun 2016 terdapat 482 kasus korupsi dengan 1101 tersangka kasus korupsi dan merugikan negara sebesar 1,47 triliun dan nilai suap sebesar 31 miliar. Hal ini juga dibuktikan oleh temuan BPK di mana BUMN masih banyak melakukan fraud. Ditinjau dari kenyataan yang ada, perusahaan telah menerapkan banyak cara dalam melakukan pencegahan dan pendeteksian atas fraud, namun fraud selalu terjadi, bahkan mengalami peningkatan dari waktu ke waktu. dikutip dalam laman Indonesian Corruption Watch (ICW, 2016), selama tahun 2016 terdapat 482 kasus korupsi dengan 1101 tersangka kasus korupsi dan merugikan negara sebesar 1,47 triliun dan nilai suap sebesar 31 miliar. Mengingat kembali kasus hambalang yang melibatkan BUMN PT. Adhi Karya yang merugikan negara hingga 706 Miliar (Tribun News, 2017). Kemudian, pada tahun 2011 terdapat indikasi korupsi dalam 
renovasi gedung oleh PT. Telkom, di mana proyek swap BTS Telkomsel dan pengadaan sim card RF untuk Telkomsel Cash (T-Cash). Atau kasus lainnya yang sedang hangat di telinga masyarakat adalah kasus korupsi ektp yang melibatkan tiga BUMN yakni; PT. PNRI, PT. LEN Industri dan PT. Sucofindo yang saat ini tengah ditangani KPK (detikNews, 2017). Padahal tidak main-main, cukup banyak BUMN yang menerapkan standar kompleks dalam aktivitas perusahaan dan pelaporan keuangan mereka, misalnya dengan menerapkan Standar Sarbanes Oxley (SOX) dan merekrut auditor internal yang memiliki sertifikasi Qualified Internal Auditor (QIA) serta Certified Fraud Examiners (CFE) dalam perusahaan. Namun tetap saja fraud tidak semudah itu dihindari. Hal ini membuktikan bahwa semaksimal apapun upaya pencegahan dan pendeteksian yang dilakukan untuk menanggulangi fraud, akan menjadi usaha yang percuma jika tidak diketahui penyebab dan pemicu dari timbulnya fraud ini. Oleh karena itu, untuk mengatasi suatu masalah, harus diketahui dulu akar masalahnya sehingga selanjutnya dapat ditemukan solusi yang tepat untuk pemecahan masalah tersebut.

Seperti pada BUMN X regional Sumatera, indikasi fraud terjadi karena adanya penggelapan aset yang dilakukan oleh pegawai tidak tetap bekerjasama dengan pihak eksternal, di mana pegawai tidak tetap yang menjadi tersangka merupakan pegawai yang bekerja tanpa mengikuti prosedur dan peraturan perekrutan karyawan, tetapi karena terdapat "link" yang memudahkan pegawai tidak tetap tersebut dapat bekerja di BUMN X (Gusti, 2016). Kondisi ini akhirnya tanpa disadari menjadi budaya yang berawal dari kebiasaan-kebiasaan buruk yang terjadi di lingkungan aktivitas BUMN. Berawal dari hal-hal yang kecil, kemudian hal tersebut menjadi faktor yang menyebabkan terjadinya fraud sehingga di dalam penelitian ini, akan dikupas secara mendalam seperti apa sebenarnya budaya-budaya "buruk" yang terjadi di BUMN $X$ regional Sumatera yang kemudian menjadi penyebab fraud di mana selanjutnya fraud yang dilakukan ini menjadi salah satu bentuk "sumbangsih" terhadap peringkat pertama BUMN X yang menjadi BUMN terkorup di Indonesia.

Penelitian sebelumnya mengenai fraud telah dilakukan oleh Liu (2016) dengan penelitian mengenai budaya korupsi di dalam perusahaan yang rata-rata dilakukan oleh pegawai dan direktur di mana budaya korupsi pada perusahaan ini berpengaruh positif terhadap perilaku buruk perusahaan. Petrascu \& Tieanu (2014) yang dilakukan dengan melihat aktivitas internal audit di perusahaan nasional dan internasional, menyimpulkan bahwa seluruh entitas memerlukan audit internal untuk efisiensi bisnis dalam arti pengelolaan harta, mencapai tujuan menengah serta jangka panjang dan melawan fraud untuk meningkatkan nilai di masa depan. Othman et al. (2015) dengan penelitiannya yang dilakukan di wilayah sektor publik Malaysia menyimpulkan bahwa, auditor internal di dalam sektor publik memainkan peran yang cukup penting dalam mendeteksi dan mencegah fraud. Penelitian yang dilakukan Abdallah, Maarof, \& Zainal (2016) yang mengamati fraud di sistem e-commerce menyimpulkan bahwa, dalam melawan fraud, pencegahan saja tidak cukup, namun juga diperlukan pendeteksian dengan 
menggunakan sistem-sistem baru dalam teknologi. Munteanu et al. (2016) yang meneliti entitas publik di Rumania menyimpulkan bahwa, internal auditor harus mempertimbangkan eksistensi dari risiko dan kesalahan pendeteksian serta harus bersikap skeptis jika terdapat beberapa laporan yang patut dicurigai. Zamzami, Nusa, \& Timur (2015) yang melakukan penelitian tentang fraud di Universitas Indonesia menyimpulkan bahwa, prosedur yang paling efektif dalam mencegah dan mendeteksi fraud adalah dengan menggunakan teknologi. Dinata (2015) yang melakukan penelitian mengenai pencegahan dan pendeteksian fraud di Badan Pemeriksa Keuangan (BPK-RI) menyimpulkan bahwa upaya dalam mencegah terjadinya fraud tidak serta-merta membuat fraud dapat diminimalisir karena pencegahan saja tidak cukup tanpa adanya pendeteksian. Penelitian Syahrina (2016) menemukan bahwa fenomena fraud di sektor pemerintahan terjadi karena budaya cari aman dan cari untung. Selanjutnya, penelitian yang dilakukan oleh Supriyono (2017) mengungkap modus fraud pengadaan aset di sektor pemerintahan. Dalam penelitian sebelumnya mengenai fraud, objek penelitian difokuskan pada sektor pemerintahan yang memiliki perbedaan dengan BUMN.

Penelitian ini akan menggunakan teknik etnografi yang akan menangkap realita mengenai budaya fraud, di mana etnografi dapat memandang sikap dan keseharian pegawai di dalam perusahaan, khususnya pegawai-pegawai yang berhubungan langsung dengan keuangan perusahaan. Selain itu, dengan menggunakan teknik ini, dapat disajikan perilaku keseharian pegawai, mulai dari cara mereka memandang pekerjaan mereka sampai dengan cara mereka berinteraksi. Sehingga akan diperoleh data dan informasi yang nantinya dapat mendeskripsikan keadaan-keadaan yang sebenarnya terjadi melalui kebiasaankebiasaan yang tanpa disadari dapat memicu terjadinya fraud. Penelitian ini akan menyingkap budaya yang menjadi penyebab fraud dengan melihat pada kebiasaan buruk yang terjadi di BUMN X bukan pada faktor lainnya seperti pribadi pelaku, atau kondisi yang memungkinkan dilakukannya fraud tetapi menekankan pada budaya di BUMN X tersebut sehingga penelitian ini diharapkan dapat memberikan kontribusi positif bagi banyak pihak.

Fraud merupakan suatu tindakan yang dianggap "gelap", melanggar norma serta peraturan hukum untuk memperoleh keuntungan bagi satu pihak dan dapat merugikan pihak-pihak yang lain. Definisi dan pengertian fraud sudah banyak dijelaskan di dalam penelitian, literatur dan lembaga. Konsep-konsep teori mengenai fraud juga sudah banyak dijabarkan, seperti teori segitiga fraud yang dicetuskan oleh Creswell, teori pohon kecurangan (fraud tree), gone theory, fraud diamond, dan lain-lain. Dalam perkembangannya, fraud dapat diartikan secara harfiah sebagai kecurangan, namun pengertian ini kemudian dikembangkan lebih dalam dan lebih luas sehingga banyak sekali definisi yang bermunculan mengenai fraud. Black's Law Dictionary menjelaskan bahwa pengertian fraud mencakup segala hal dalam pikiran manusia yang dapat diusahakan untuk mendapatkan keuntungan dari orang lain dengan cara yang salah, baik itu dengan melakukan pemaksaan kebenaran, atau hal- 


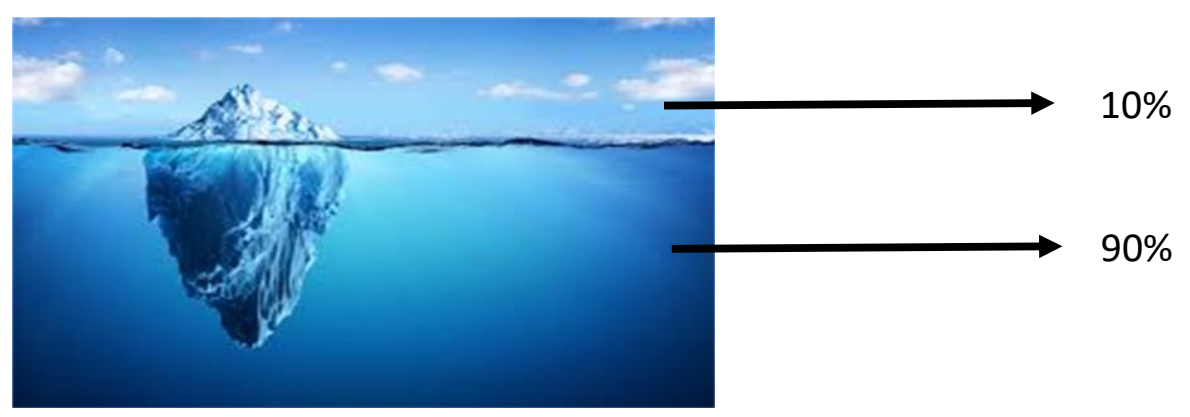

Gambar 1. Fenomena Iceberg

hal yang tidak terduga serta penuh siasat licik, tersembunyi dan hal-hal lainnya yang tidak jujur dan menyebabkan orang lain tertipu. Selanjutnya, di dalam konsep fraud, terdapat fenomena gunung es (iceberg), di mana dalam fenomena ini dijelaskan bahwa fraud merupakan suatu skandal kolutif yang hanya menunjukkan sebagian kecil fakta apabila fraud tersebut terungkap.

Fraud Tree atau pohon kecurangan diistilahkan oleh Tuanakotta (2013) sebagai peta kecurangan atau fraud taxonomy dalam fraud tree disajikan klasifikasi atau kategori dari berbagai bentuk fraud. Dalam fraud tree terdapat 3 cabang utama, yaitu; korupsi (corruption), penyalahgunaan aset (asset misappropriation) dan kecurangan dalam laporan keuangan (fraudulent statement).

Teori lainnya mengenai fraud adalah fraud triangle, teori ini pada awalnya merupakan gagasan dari seorang mahasiswa yang bernama Donald R. Cressey (1953) menyimpulkan terdapat kondisi yang selalu hadir dalam kegiatan kecurangan perusahaan yakni yaitu tekanan/motif, kesempatan, dan rasionalisasi. Perkembangan selanjutnya adalah fraud scale merupakan teori yang dicetuskan oleh Dr. Steve Albrecht bersama dua koleganya, Howe dan Romney melalui penelitian yang mereka lakukan mengenai Fraud Deterring;
Internal Auditor Perspective. Dalam fraud scale dijelaskan bahwa terdapat 10 faktor yang paling tinggi dalam karakteristik personal yaitu; gaya hidup melebihi kemampuannya; keinginan yang meluapluap untuk keuntungan pribadi; terjerat utang yang besar; hubungan yang dekat dengan nasabah/pelanggan; merasa imbalan yang diterima tidak sepadan dengan tanggung jawabnya; sikap seperti pedagang "liar"; tantangan yang kuat untuk menaklukkan atau menyiasati sistem; kebiasaan berjudi yang berlebihan; tekanan dari pasangan atau keluarga yang berlebihan; tidak ada pengakuan untuk kinerjanya (Priantara, 2013).

Banyak penelitian yang menemukan bahwa terjadinya fraud dikarenakan seseorang yang memiliki tekanan dalam melakukan fraud. Diamond Fraud di mana konsep ini mempertimbangkan kemampuan individu atau kapabilitas dalam melakukan fraud selain, tekanan, kesempatan dan rasionalisasi. Fraud Pentagon merupakan perkembangan dari teori Fraud Diamond. Di mana di dalam fraud diamond dijelaskan bahwa terdapat empat elemen penyebab fraud yaitu insentif (tekanan), peluang, rasionalisasi dan kemampuan (capability), yang kemudian di kembangkan dalam fraud pentagon dengan menambah dua elemen 
lagi yaitu, kesombongan (arrogance) dan kompetensi (competence). Selanjutnya, Fraud Star yang dikembangkan oleh Irianto (2010) faktor yang tidak kalah penting adalah integritas (integrity). Integritas dalam hal ini dianggap faktor yang cukup penting, karena integritas merupakan faktor penentu individu akan melakukan fraud atau tidak. Sementara dalam teori faktor pemicu kecurangan terdapat empat faktor pendorong seorang untuk melakukan kecurangan, yang disebut juga dengan GONE Theory yaitu; keserakahan (greed), kesempatan (opportunity), kebutuhan (need), pengungkapan (exposure). Teori ini dicetuskan oleh G. Jack Bologna dalam Tuanakotta (2013).

Lalu, bagaimana kemudian fraud dapat dikaitkan dengan budaya melalui kebiasaankebiasaan yang terjadi di dalam suatu organisasi? Dalam hal ini, salah satu tokoh terkenal di Indonesia Koentjaraningrat mendefinisikan budaya sebagai daya budi yang berupa rasa, cipta dan karsa sementara kebudayaan merupakan hasil dari rasa, cipta dan karsa itu sendiri. Hal ini didasarkan pada definisi budaya yang berasal dari bahasa sanskerta "buddhayah" yang merupakan bentuk jamak dari buddhi yaitu budi atau akal. Lebih lanjut Tylor (1971), tokoh antropologi Inggris mendefiniskan budaya atau kebudayaan merupakan suatu keseluruhan yang kompleks di mana di dalamnya terkandung kepercayaan, moral, hukum, adat istiadat, pengetahuan, dan kemampuan lainnya yang didapat oleh seseorang sebagai anggota masyarakat.

Miller \& Dollard (1941) mendefinisikan kebiasaan (habit) sebagai ikatan atau asosiasi antara stimulus dengan respon yang relatif stabil dan bertahan lama dalam kepribadian. Gambaran kebiasaan seseorang tergantung pada kejadian khas yang menjadi pengalamannya. Kebiasaan ini juga muncul dari dorongan-dorongan yang berasal dari pribadi individu dan juga dari lingkungan tempat individu beraktivitas. Schein dalam Luthans (2011) mendefiniskan budaya organisasi sebagai bentuk dari asumsi dasar yang ditemukan dan dikembangkan oleh suatu kelompok tertentu untuk mengatasi masalah eksternal dan internal di mana bentuk asumsi tersebut dianggap baik dan bernilai sehingga perlu diterapkan sebagai cara yang benar untuk menerima, berpikir dan merasakan setiap masalah yang terjadi di dalam organisasi. Budaya dan budaya organisasi merupakan satu kesatuan yang tidak dapat dipisahkan. Hal ini dapat dilihat dari budaya yang merupakan sebuah genus sementara budaya organisasi adalah spesi dari budaya tersebut yang terbentuk sebagai produk interaksi antara manusia dan jaringan organisasi.

Budaya kerja merupakan suatu pemikiran dasar dan program mental yang dapat digunakan untuk meningkatkan efisiensi kerja dan kerjasama manusia yang terdapat di dalam suatu golongan masyarakat (Ndraha, 2005). Budaya kerja tentunya tidak terlepas dengan budaya organisasi, di mana di dalam budaya organisasi lebih mengarah kepada objek atau tempat di mana budaya dapat muncul melalui interaksi, sedangkan budaya kerja lebih mengarah kepada sikap dan cara seseorang atau suatu kelompok dalam menjalankan kegiatan kerjanya. Dalam penelitian ini, situs penelitian merupakan Badan Usaha Milik Negara (BUMN) di mana 
BUMN memiliki perbedaan dengan sektor publik. Menurut Mardiasmo (2009:2), sektor publik adalah sebuah entitas yang didirikan untuk menghasilkan barang ataupun pelayanan publik di mana hal-hal tersebut untuk menjamin kesejahteraan publik dan dapat memenuhi hak-hak publik. Sedangkan BUMN atau badan usaha milik negara adalah suatu entitas yang sebagian besar sahamnya dimiliki oleh negara di mana kegiatan dan aktivitasnya tidak hanya memberikan layanan kepada masyarakat tetapi juga berorientasi pada keuntungan atau laba yang akan dicapai untuk memberikan keuntungan bagi negara.

Dilihat dari tingkat fraud pada kas di BUMN yang mencapai persentase sebesar 68,66\% mengindikasikan bahwa fraud telah menjalar tidak hanya di setiap divisi dalam BUMN, tetapi juga memanfaatkan celah yang ada dari berbagai kesempatan (Sekarwulan, 2008). Menurut Sukardi (2004) dalam salah satu situs berita terkemuka di Indonesia, dijelaskan bahwa BUMN sangat kental sekali dengan budaya KKN (Korupsi, Kolusi, Nepotisme) sehingga hal ini yang kemudian menjadi pemicu terjadinya fraud yang menyebabkan kerugian negara. Bahkan kerugian negara di tahun 2017 ditaksir hingga 5,8 triliun rupiah karena kerugian yang dialami oleh BUMN (Ismoyo, 2017).

Penelitian yang dilakukan oleh Liu (2016) mengenai Corruption Culture and Corporate Misconduct di mana dalam penelitian yang dilakukannya dapat disimpulkan bahwa budaya korupsi di suatu perusahaan, ratarata merupakan perilaku pegawai dan direktur perusahaan dengan menggunakan informasi latar belakang budaya mereka dan budaya korupsi di dalam perusahaan secara positif berdampak pada perilaku buruk perusahaan. Valcarcel et al. (2017) meneliti tentang fraud yang dianggapnya menular. Hal ini dapat dilihat dari hasil temuan di dalam penelitiannya bahwa, fraud dapat terjadi karena budaya seseorang disertai dengan latar belakang ekonominya. Barr et al. (2010) melakukan penelitian eksperimental mengenai korupsi dan budaya di mana mahasiswa tingkat akhir dan mahasiswa yang telah lulus menjadi objek penelitiannya hasil eksperimen yang dilakukan pada mahasiswa yang sudah lulus menunjukkan bahwa peneliti tidak dapat menentukan siapa yang cenderung akan melakukan korupsi dan siapa yang tidak. Davis \& Pesch (2013) yang melihat dinamika fraud di dalam organisasi, di mana individuindividu heterogen yang saling berinteraksi antara satu sama lain beberapa di antaranya memiliki motif dan peluang untuk melakukan fraud. Firfiray et al. (2017) kemudian meneliti tentang nepotisme di dalam perusahaan keluarga dimana nepotisme yang terjadi sebenarnya dapat berdampak positif bagi perkembangan perusahaan ketika yang menjadi objeknya adalah perusahaan yang didirikan dan dimiliki oleh keluarga itu sendiri. Sebaliknya, nepotisme akan berdampak negatif jika dilakukan di dalam perusahaan yang bukan merupakan milik keluarga. Dalam penelitian yang dilakukan Schwatz (2013) dijelaskan bahwa membangun etika budaya perusahaan yang dilengkapi dengan tiga pilar yakni; etika kepemimpinan, etika basic values, dan program etika dapat membentuk budaya perusahaan yang terbebas dari fraud. 


\section{METODE}

Penelitian kualitatif bertujuan untuk menjelaskan realita dan makna dalam kondisi yang sebenarnya. Selain itu juga memberikan penjelasan yang jauh lebih mendalam sehingga fenomena yang terjadi berdasarkan kenyataan yang sebenarnya dapat dideskripsikan secara detail dan tuntas. Tujuan dalam penelitian ini adalah untuk mengeksplorasi fenomena-fenomena yang terjadi berdasarkan situasi sosial dengan melihat pada perilaku dan keadaan yang terjadi di dalam suatu perusahaan mengenai masalah-masalah yang menjadi penyebab munculnya fraud sehingga paradigma yang tepat untuk digunakan di dalam penelitian ini adalah paradigma interpretif. Penelitian ini dilakukan tidak hanya sebatas melihat bagaimana fraud terjadi karena kesadaran pelaku, namun melihat bagaimana sebenarnya kebiasaan dan budaya yang terbentuk di dalam suatu perusahaan tanpa disadari dapat menjadi penyebab terjadinya fraud sehingga peneliti yakin bahwa metode yang tepat untuk penelitian ini adalah metode etnografi yang bertujuan untuk menjawab pertanyaan-pertanyaan mengenai bagaimana kebiasaan dan budaya serta perilaku seseorang di dalam perusahaan dapat menjadi penyebab munculnya fraud. Karena suatu budaya tidak akan pernah terlepas dari kehidupan manusia bahkan dari suatu organisasi.

Selanjutnya, dalam metode etnografi pada penelitian ini akan digunakan alur Developmental Research Sequence (Alur Maju Bertahap). Strategi penulisan etnografi menurut Spradley mencakup lima prinsip yaitu; memilih teknik pengumpulan data, mengenali langkah-langkah penelitian, menjalankan setiap langkah secara berurutan, melakukan praktik penelitian secara orisinil, dan memberikan pemecahan masalah sebagai bentuk tanggung jawab sosial.

Situs penelitian yang digunakan adalah salah satu Badan Usaha Milik Negara (BUMN) go public di Indonesia yang tidak terhindar dari kasus fraud. Alasan memilih situs penelitian pada BUMN $X$ adalah selain menambah wawasan keilmuan tentang fraud, juga untuk mengetahui budaya dan kebiasaan yang terjadi di dalam suatu lingkungan BUMN. Mengapa BUMN yang tergolong sangat besar, dengan segala jenis kompleksitas peraturan dan kompetensi pegawainya masih saja tersandung kasus fraud? Budaya seperti apa yang diterapkan? Alasan terakhir mengapa peneliti memilih situs penelitian pada BUMN X adalah adanya akses terkait dengan situs penelitian. Di dalam penelitian kualitatif adanya akses di dalam situs penelitian merupakan hal yang penting sehingga dapat mempermudah peneliti dalam mengorek informasi mengenai fokus penelitian yang menjadi tujuan utama peneliti.

Objek dalam penelitian ini adalah budaya di dalam perusahaan yang berhubungan dengan aktivitas perusahaan baik dalam bagian keuangan maupun bagian sumber daya manusia yang dapat dilihat dari perilaku pegawainya dalam melaksanakan kegiatan-kegiatan di lingkungan BUMN. Dalam penelitian ini, budaya BUMN X yang menjadi objek penelitian adalah budaya di BUMN X regional Sumatera yang terletak di Medan, Sumatera Utara di mana BUMN X regional Sumatera ini menyumbang keuntungan sebesar 20-30\% untuk BUMN X 
secara nasional dari total keuntungan yang didapat mencapai 13 triliun rupiah per tahun meskipun jumlah keuntungan ini berfluktuasi setiap tahunnya. Dalam penelitian kualitatif, yang menjadi instrumen utama adalah penelitiannya sendiri di mana hal ini dapat terjadi karena manusia adalah satu-satunya alat yang mampu mengumpulkan data.

Teknik pengumpulan data yang digunakan dalam penelitian ini meliputi tiga hal yaitu wawancara, observasi dan dokumentasi. Di dalam tahap pengumpulan data, terdapat dua tahap yang harus dilakukan peneliti. Yang pertama adalah pengumpulan data awal. Dalam melakukan pengumpulan data awal, peneliti harus melebur ke dalam lingkungan perusahaan yang bersentuhan langsung dengan masalah fraud. Tahap selanjutnya, adalah pengumpulan data terfokus. Pada tahap ini, peneliti sudah menemukan pelaku fraud dan gambaran budaya pelaku, sehingga selanjutnya peneliti perlu melakukan eksplorasi mendalam mengenai pelaku sebagai cara untuk mengetahui budayabudaya penyebab fraud melalui tindakan maupun aktivitas kesehariannya. Terdapat beberapa teknik dalam melakukan analisis data pada penelitian. Penelitian model Alur Maju Bertahap yang membutuhkan konfirmasi di setiap analisisnya mencakup empat prosedur penelitian yaitu analisis domain, analisis taksonomi, analisis komponensial dan analisis tema budaya.

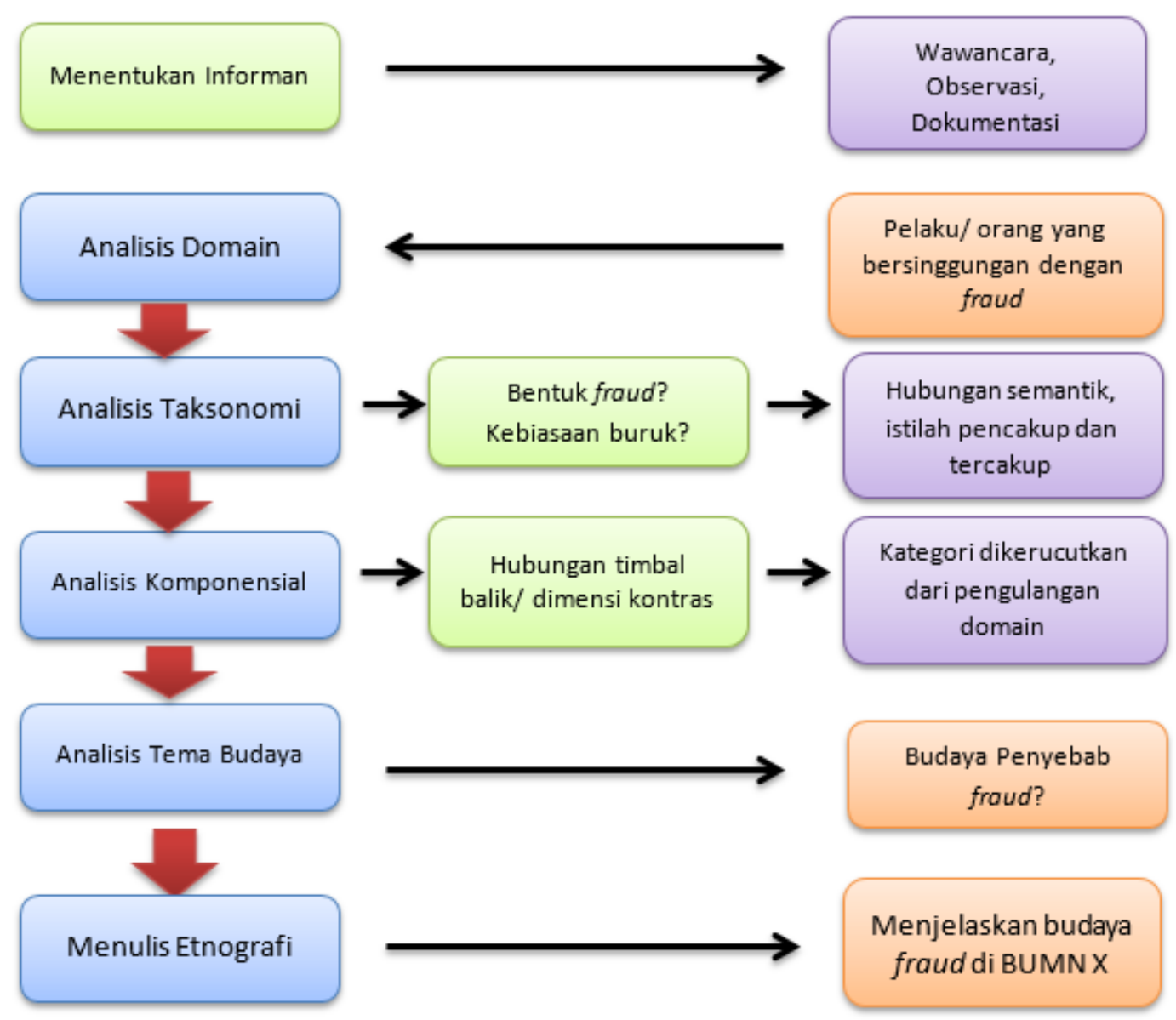

Gambar 2. Alur Penelitian 
Selanjutnya, dalam penelitian ini teknik keabsahan data hanya dilakukan dalam tiga tahap yaitu dengan melakukan perpanjangan pengamatan, mengkonfirmasi apa yang diamati dan apa yang menjadi hasil dari wawancara tersebut, serta meningkatkan ketekunan dan terakhir adalah triangulasi.

\section{HASIL DAN PEMBAHASAN}

Keterkaitan dengan apa yang ingin diteliti, penting sekali untuk mengetahui objek dan ruang lingkup di mana penelitian akan dilakukan. Pada penelitian ini, peneliti memulai observasi di ruangan human capital BUMN X di mana di dalam lingkup ini terjadi interaksi mengenai segala hal tentang sumber daya manusia (SDM) baik dari awal perekrutannya hingga pembagian tugas dan jabatan yang harus diemban oleh pegawai yang menjadi "akar" masalah atau pemicu fraud dapat terjadi. Jika mengikuti sistem dan prosedur yang ada, perekrutan karyawan misalnya harus melalui tahap-tahap seperti tes administrasi yang sesuai dengan kualifikasi yang diberikan oleh perusahaan, kemudian tes kemampuan dasar dan bidang yang ditekuni melalui seleksi online, tes wawancara, dan terakhir tes kesehatan. Apabila kandidat peserta lulus dalam rangkaian tahapan tes tersebut, kandidat akan menjadi calon pegawai yang di training terlebih dahulu sebelum terjun ke dalam aktivitas BUMN $\mathrm{X}$, dan pengangkatan pegawai tetap juga memerlukan waktu yang tidak sebentar setelah melaksanakan training. Namun demikian, di dalam BUMN X ada beberapa pegawai yang ternyata bekerja tanpa mengikuti syarat dan prosedur tersebut. Hanya karena mereka memiliki link di dalam perusahaan, mereka dapat bekerja hanya dengan mengandalkan beberapa keperluan administratif. Pada keadaan ini, kandidat pegawai yang tidak mengikuti prosedur akan ditempatkan sementara sebagai tenaga honorer dan akan diangkat menjadi pegawai hanya dalam kurun waktu tiga bulan.

Hal lainnya yang terjadi di dalam BUMN $X$ adalah, secara prosedural, pengangkatan pegawai untuk jabatan baru hanya bisa terjadi selama dua tahun sekali, tetapi ada beberapa pegawai yang bekerja di suatu jabatan, hanya dalam kurun waktu satu tahun, beliau sudah menduduki jabatan satu tingkat di atas jabatan yang sebelumnya. Padahal, seharusnya ada beberapa hal yang perlu diperhatikan dalam proses pengangkatan pegawai ini, di antaranya adalah melihat kompetensi pegawai tersebut, kesiapan pegawai tersebut dalam menjabat di bagian sebelumnya, serta keahlian pegawai apakah sudah cukup dan matang di jabatan sebelumnya atau masih memerlukan proses lagi hingga akhirnya dapat menduduki jabatan baru dalam perusahaan. Masalah mengenai ketidaksesuaian kompetensi dengan jabatan yang harus diduduki seorang pegawai memang terlihat sepele dan banyak orang beranggapan bahwa kompetensi yang dibutuhkan seseorang dapat diperoleh dari pelatihan. Namun demikian, ketika hal ini sudah bersinggungan dengan kebutuhan perusahaan tentunya ini akan menjadi hal yang berbeda. Permasalahannya tidak hanya sebatas itu. Hal ini diungkapkan oleh sekretaris jenderal serikat karyawan BUMN $X$, pak Fandi. 
"Bukan masalah sepele sih kalau mengenai ketidaksesuaian kompetensi dengan penempatan jabatan pegawai. Malah bisa dibilang ini yang memicu masalah-masalah lainnya terjadi. Lebih parahnya, bahkan bisa memicu adanya fraud. Karena ya itu tadi, ada kesempatan, dan semua terlihat aman-aman saja."

Ketidaksesuaian kompetensi dengan jabatan yang diduduki pegawai tidak hanya terjadi karena kebutuhan perusahaan atau slot jabatan kosong yang harus diisi saja. Tetapi juga karena hal-hal lain seperti keinginan seseorang untuk dapat menduduki suatu jabatan dengan cepat, ingin naik pangkat, dan ada orang lain yang menolong untuk mendapatkan suatu posisi. Ditambah dengan kesempatan dan peluang yang ada di perusahaan tadi, maka komplitlah permasalahan ini. Pegawai yang menduduki jabatan dapat berdalih bahwa hal ini bukan merupakan kesalahan mereka tetapi karena kebutuhan perusahaan yang mendesak padahal faktor utama yang menimbulkan masalah ini adalah sumber daya manusianya. Inilah nepotisme. Dari nepotisme ini kemudian seluruhnya menjalar hingga membentuk pola fraud yang selama ini tidak banyak diketahui. Hal ini yang akhirnya harus dihadapi oleh perusahaan. Sesuatu yang tadinya dianggap kecil, kemudian merembet dan membentuk permasalahan yang cukup besar. Kebiasaan ini dibenarkan oleh Kak Yuri yang merupakan salah satu informan dalam penelitian ini. Berikut pernyataan dari Kak Yuri;

"Biasa, kalau soal itu. Gak usah ditanya, namanya juga sudah dekat sama boss. Jangankan setahun lebih, 6 bulan aja pun kalo memang udah boss bilang bisa naik ya naik langsung jabatannya hahaha."

Pernyataan Kak Yuri yang merupakan informan kunci dan salah satu staff di bagian SDM menunjukkan bahwa hal yang terjadi mengenai ketidaksesuaian prosedur dengan kenyataan mengenai kenaikan jabatan pegawai merupakan suatu hal yang sudah lumrah dan biasa. Keadaan ini mengindikasikan bahwa apapun bisa dilakukan selama seorang pegawai memiliki kedekatan dengan atasan tanpa perlu khawatir dengan prosedur dan sistem yang seharusnya dijalankan. Selain itu, hal lainnya yang ditemukan dalam observasi ini juga ada beberapa pegawai baru yang sudah diangkat menjadi pegawai tetap padahal baru saja bekerja selama delapan bulan. Padahal untuk menjadi pegawai tetap dengan sistem masuk tenaga honorer, untuk diangkat menjadi pegawai tetap paling cepat adalah selama dua tahun. Dan untuk menutupi keadaan ini saat direksi akan datang mengunjungi BUMN $X$, pegawai honorer yang baru saja diangkat menjadi pegawai tetap kemudian di rotasi ke perusahaan anak BUMN $X$ agar tidak ditemukan kejanggalan dalam penempatan pegawai honorer. Permasalahanpermasalahan ini kemudian tanpa disadari menjadi satu kebiasaan yang akhirnya merembet ke banyak hal. Dari ketidaksesuaian kompetensi pegawai hingga pegawai yang direkrut karena memiliki akses orang dalam memberikan dampak yang cukup serius bagi perusahaan dan memberikan masalah baru yang tanpa disadari merupakan suatu bentuk fraud.

"Wah, kalo masalah yang ada di sini ya banyak. Ada pegawai yang kedapatan 
bawa kabel-kabel punya perusahaan, di jual lagi sama orang tapi mengatasnamakan perusahaan, padahal kelakuannya sendiri itu, ada yang sempat berusaha nyogok pejabat biar jabatannya naik, ya ada juga pegawai kita yang ngurus-ngurus soal naik jabatan ngerasa gak enak dia kalo gak nolong. Namanya pun sama kawan. Banyak lah. Semua masalahnya ya masuk ke kami. Itulah tadi, awal mulanya kan karena dipikir semua itu udah kebiasaan, udah rahasia umum lah, makanya mau cemana lagi? Nepotisme disini kental kali, gak bisa dihindarkan, makanya jadi merembet kemana-mana."

Pernyataan tersebut diungkapkan oleh Pak Lukito yang merupakan General Manager Human Capital BUMN $X$ regional Sumatera. Selanjutnya, menurut beliau kejanggalan dalam hal ini juga dapat dilihat dari dokumen surat keputusan pegawai yang penempatannya tidak sesuai dengan background keahlian dan pendidikan pegawai yang menyebabkan seluruh pekerjaan yang seharusnya dapat ditangani dengan baik menjadi tidak beres dan berdampak ke hal-hal lainnya seperti seorang pegawai yang terbiasa menangani keluhankeluhan konsumen atau menjabat sebagai manager customer care kemudian ditempatkan menjadi manager umum di divisi access optima, di mana dalam divisi ini, job description pegawai tersebut adalah menangani masalah akses jaringan dan sistem. Tentu saja hal ini sangat bertolak belakang dengan keahlian dan kompetensi pegawai sehingga karena ketidaksesuaian ini, pekerjaan di divisi access optima menjadi tidak optimal karena banyak jaringanjaringan yang bermasalah dan tidak dapat ditangani dengan baik oleh bawahan manager baru tersebut sehingga mengakibatkan kerugian bagi BUMN $X$. Ketika jaringan-jaringan yang harusnya berfungsi dengan optimal dan memberikan keuntungan, malah menjadi suatu kerugian yang menyebabkan para pelanggan mengeluh dan mengancam tidak akan menggunakan produk wifi dari BUMN $X$. Contoh dokumen surat keterangan yang tidak sesuai dengan jabatan pegawai sebelumnya dapat dilihat pada Gambar 3.

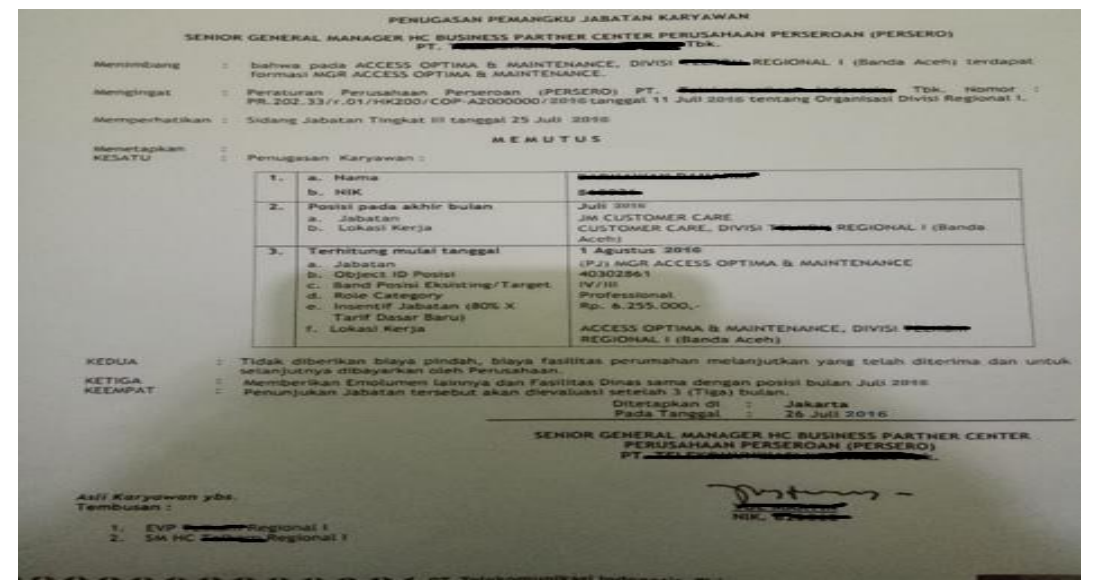

Gambar 3. Bukti Dokumen 


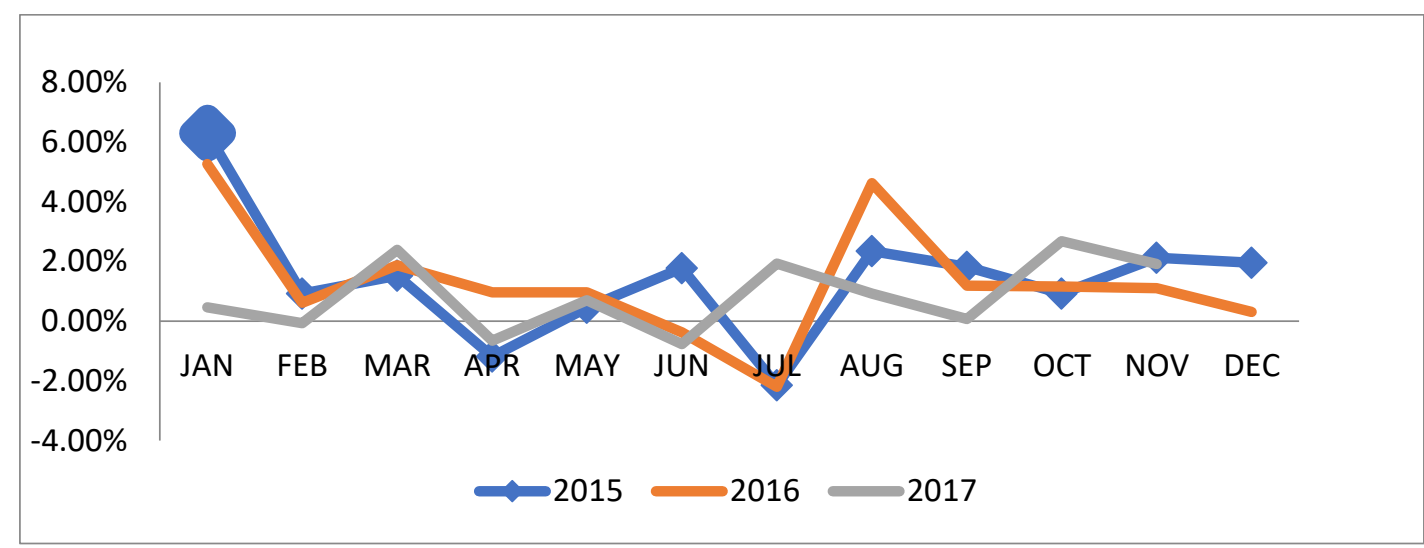

Gambar 4. Kinerja Keuangan BUMN X Reg. Sumatera

Berdasarkan data yang diperoleh mengenai surat keputusan pegawai dengan rolling jabatan yang tidak sesuai dengan background atau kompetensi seorang pegawai sebelumnya, ternyata hal ini memberikan dampak yang cukup serius bagi instansi. Kendati seluruh aktivitas dan operasional perusahaan dianggap bisa amanaman saja, namun yang terjadi malah sebaliknya. Misalnya, ketika seorang pegawai yang awalnya tidak menangani masalah access optima seperti yang ditunjukkan pada bukti SK di atas, dan kemudian harus menangani hal tersebut, terjadi banyak komplain pelanggan seperti keluhan karena kerusakan jaringan yang tidak kunjung diperbaiki sehingga konsumen merasa kecewa dan memutuskan untuk melakukan pemutusan jaringan dan kemudian memilih untuk berhenti berlangganan produk jasa dari BUMN X. Hal ini dijelaskan di dalam tulisan dan keluhan pelanggan yang mengatakan bahwa kerusakan yang terjadi tidak segera ditangani oleh pihak BUMN $X$ selama sepekan lebih (Tjandinegara, 2017). Kerugian ini tidak hanya dirasakan oleh pihak konsumen namun juga berdampak pada penurunan pendapatan instansi karena beberapa hal mengenai nepotisme yang kerapkali dilakukan di dalam instansi yang saat ini telah menjadi budaya. Data kinerja keuangan BUMN $X$ setelah adanya rolling jabatan yang tidak sesuai dengan kompetensi dan background pegawai dapat dilihat pada Gambar 4 dan Gambar 5.

Dalam penelitian etnografi, sebelum fokus pada informan kunci, terlebih dahulu harus ditemukan domain-domain dari

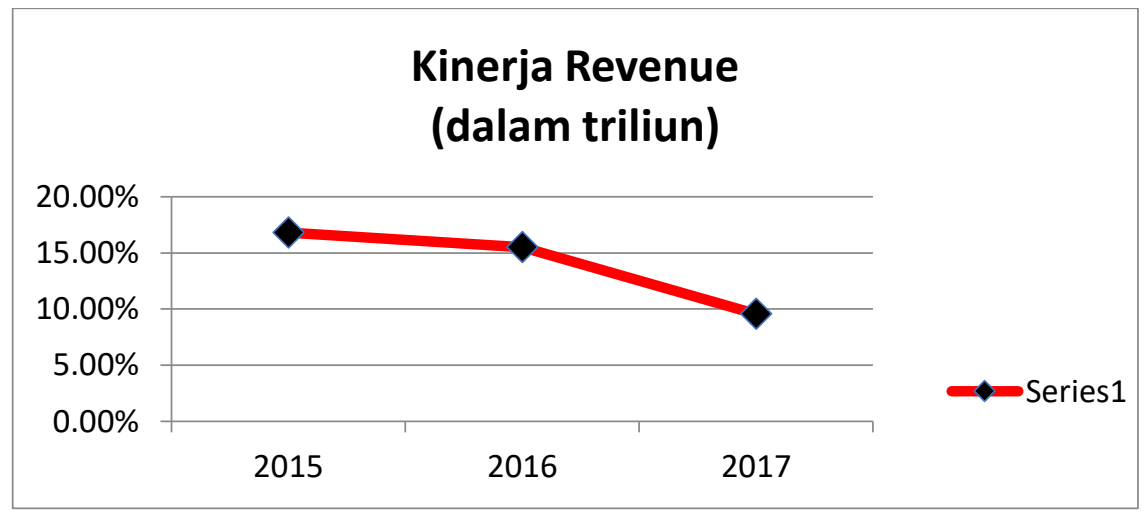

Gambar 5. Kinerja Revenue setelah Rolling Jabatan 
pengumpulan data awal yang nantinya akan dianalisis hingga menemukan tema budaya atas sebuah penelitian etnografi. Hal yang menarik adalah, budaya-budaya yang terbentuk awalnya berasal dari karakter atau ciri khas individu sebagai penduduk asli kota Medan yang memegang prinsip CK Kental = Solidaritas Tinggi yang akhirnya melahirkan budaya-budaya seperti semua bisa diatur dan prosedur hanya formalitas. Beberapa analisis dilakukan dalam menemukan tema budaya, yakni analisis domain yang dihasilkan dari pengulangan domain-domain yang muncul atas wawancara, observasi dan dokumentasi dengan menemukan hubungan semantik antara istilah pencakup dan istilah tercakup, selanjutnya dikecurutkan di dalam analisis taksonomi dengan memilah domain yang lebih seiring muncul, untuk kemudian dilakukan analisis komponensial dengan cara membuat rangkaian kontras atas domain yang muncul tersebut, sehingga dapat membentuk analisis tema budaya.

Dalam penelitian ini, diperoleh hubungan antara subsistem yang dapat dijelaskan bahwa pola perilaku pegawai BUMN X Reg. Sumatera yang didasari oleh sifat manusia yang pada dasarnya tidak bisa menolak permintaan bantuan orang lain, dan tidak tega terhadap keadaan sekelilingnya membuat orang lain dengan sifat manusia ini pula mencari kesempatan dan berpikir bahwa "selama ada orang dalam yang bisa membantu kenapa tidak dimanfaatkan" yang akhirnya berujung pada munculnya indikasi nepotisme dan menjadi penyebab fraud karena ketidakberesan dalam pekerjaan dan merasa aman-aman saja bila suatu kesalahan dilakukan dengan sengaja.

Dalam kaitannya dengan tuntutan instansi, juga berasal dari instansi yang membutuhkan pegawai untuk mengisi slot jabatan yang kosong demi kelancaran aktivitas perusahaan yang sebenarnya tidak jarang jabatan kosong tersebut diisi oleh pegawai yang tidak berkompetensi di bidang tersebut sehingga megakibatkan kelalaian dan pekerjaan yang hasilnya tidak sesuai sehingga mengakibatkan adanya celah yang dapat digunakan oleh pegawai lainnya untuk melakukan fraud.

Rasionalisasi atas peluang yang ada terjadi karena terdapat kesempatan dan celah yang bisa dimanfaatkan untuk melakukan nepotisme yang akhirnya berdampak pada fraud. Misalnya, ketika seorang pegawai merasa semua hal dapat diatur karena ada orang dalam yang menanganinya ditambah dengan celah yang ada karena kebutuhan instansi, hal ini kemudian dapat menjadi pemicu timbulnya fraud.

Tabel 1. Hasil Analisis Tema Budaya

\begin{tabular}{llll}
\hline \multicolumn{1}{c}{ Analisis Domain } & Analisis Taksonomi & \multicolumn{1}{c}{$\begin{array}{c}\text { Analisis } \\
\text { Komponensial }\end{array}$} & Analisis Tema \\
\hline $\begin{array}{l}\text { Alasan } \\
\text { dilakukannya } \\
\text { nepotisme yang } \\
\text { berimplikasi pada } \\
\text { fraud }\end{array}$ & $\begin{array}{l}\text { Pola Perilaku } \\
\text { Pegawai }\end{array}$ & Manusia & Semua Bisa Diatur \\
\cline { 2 - 4 } & Tuntutan instansi & $\begin{array}{l}\text { Kepentingan } \\
\text { instansi }\end{array}$ & $\begin{array}{l}\text { Prosedur hanya } \\
\text { formalitas }\end{array}$ \\
\cline { 2 - 4 } & $\begin{array}{l}\text { Rasionalisasi atas } \\
\text { peluang yang ada }\end{array}$ & Manusia & Semua bisa diatur \\
\hline
\end{tabular}


Berdasarkan hubungan-hubungan yang terbentuk di atas, tema budaya yang paling tepat menggambarkan kondisi BUMN $X$ dijabarkan pada Tabel 1 dan Gambar 6.

Di dalam BUMN X Regional Sumatera ini, karakter yang cukup kuat adalah "CK Kental." Istilah ini selalu digunakan oleh masyarakat di Medan untuk menggambarkan keakraban yang terjadi antara dua atau beberapa pihak. Inilah solidaritas, atau dapat pula dimaksud dengan tenggang rasa. Karakter ini mungkin dianggap biasa bagi banyak orang secara umum, tetapi sangat berbeda dan terasa sekali jika berada di BUMN X Reg. Sumatera. Keadaan ini ditandai oleh tidak adanya batas antara pekerjaan dan masalah pribadi.
Sehingga dari karakter ini, lahirlah budayabudaya yang menjadi penyebab fraud.

Budaya "Cincai-cincai lah"

Budaya ini merupakan istilah yang kerapkali digunakan oleh pegawai BUMN X Regional Sumatera untuk menggambarkan bahwa semua hal dapat diatur. Budaya semua bisa diatur ini lahir dari kebiasaankebiasaan berikut.

Pertama, kebiasaan menolong yang tidak pada tempatnya. Kebiasaan yang cukup kental di instansi ini adalah kebiasaan menolongnya. Hal ini diutarakan oleh pegawai BUMN X yang memiliki keterkaitan terhadap indikasi fraud yang berawal dari nepotisme atas kebiasaan-kebiasaan yang

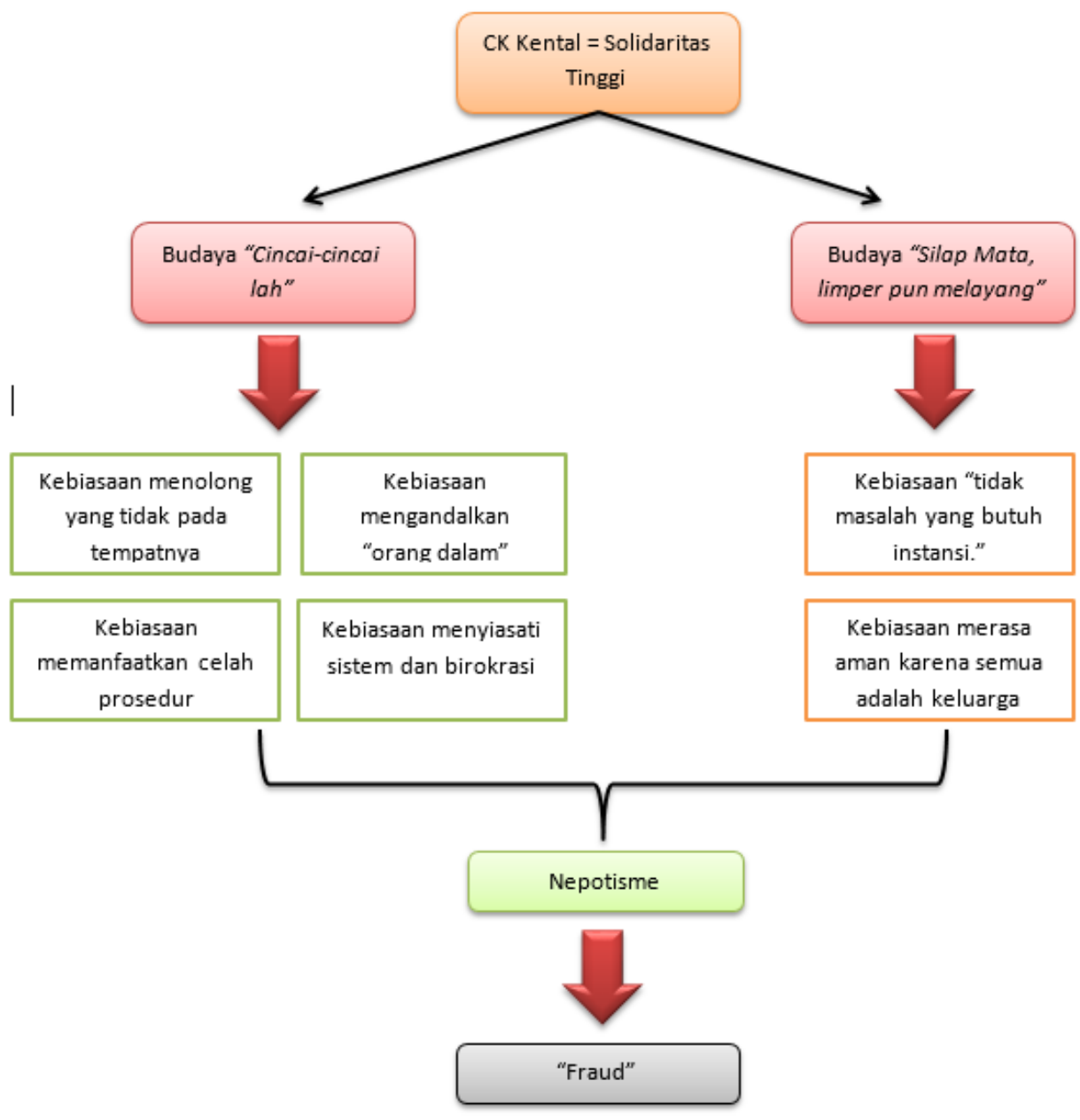

Gambar 6. Skema Temuan Penelitian 
terjadi dalam aktivitas di instansi. Berikut penuturan dari Pak Lukito;

"Masa teman sendiri gak ditolong? Lagian dulu dia pernah bawain saya oleh-oleh mahal dari luar negeri. Sekarang, giliran dia butuh bantuan ya saya tolong lah. Mumpung saya masih bisa nolong."

"Memang kalo untuk bagian keuangan, dan lainnya kita udah mulai bisa meminimalisir fraud ini. Tapi saya akui kalo untuk bagian SDM sendiri memang susah, karena ini sudah menjadi kebiasaan, sudah menjadi budaya dan memang tidak bisa saya pungkiri kalau dari hal-hal yang terlihat sepele ini justru menimbulkan masalah lain yang berimplikasi pada fraud dan jadi semakin sulit di deteksi. Tapi mau bagaimana lagi? Kadang saya juga gak bisa nolak, mikir juga kalo saya di posisi itu mungkin saya akan melakukan hal yang sama. Selagi masih ada kesempatan."

Pak Fandi sendiri yang merupakan pejabat kelas atas dalam menangani masalah-masalah seperti fraud saja bisa memberikan pendapat bahwa memang hal ini telah menjadi budaya yang sulit untuk dihindari di instansi ini. Budaya menolong yang tidak pada tempatnya ini tidak hanya terjadi di kalangan pegawai tetap yang menginginkan kenaikan jabatan saja, tetapi juga merembet kepada pegawai tetap yang sengaja membawa sanak saudaranya untuk bekerja di instansi ini tanpa proses rekrutmen yang seharusnya diikuti oleh setiap calon pegawai. Contoh kasus yang terjadi di BUMN X ketika salah satu pegawai membantu saudaranya untuk bekerja sebagai satpam di BUMN X, hal ini dilakukan seorang pegawai karena merasa kasihan melihat saudaranya yang sulit mendapatkan pekerjaan. Akhirnya, dengan kesempatan yang dimiliki oleh seorang pegawai tersebut, beliau membantu saudaranya untuk bekerja di BUMN X.

Seperti Bang Bobi, yang merupakan salah satu pegawai bagian keuangan yang di bantu oleh saudaranya agar bisa naik jabatan menjadi officer 3 dan dipindahtugaskan di BUMN X padahal sebelumnya bang Bobi malah harus ditempatkan di Jawa Tengah. Saat itu Bang Bobi merasa posisinya sedang terancam sebagai seorang auditor internal, karena beberapa kali Bang Bobi mangkir dari pekerjaan auditnya. Banyak temuan yang ditemukan oleh auditor eksternal baik dari segi pengendalian internal maupun dari kesalahan pengungkapan laporan keuangan. Hal ini menjadi alasan Bang Bobi untuk mengajukan surat pindah ke divisi lain sebelum terjadi hal-hal yang tidak diinginkan karena kecerobohannya dalam melakukan pekerjaan. Karena hal itulah kemudian Bang Bobi meminta pertolongan kepada petinggi perusahaan yang juga memiliki hubungan dekat dengan salah satu direksi instansi agar secepat mungkin Bang Bobi dipindahkan ke divisi lain. Di sini, selain meminta untuk dipindahkan ke divisi lain, Bang Bobi juga minta tolong kepada petinggi instansi agar dipindahkan ke daerah asalnya di Medan. Padahal, sebenarnya jika mengikuti prosedur perusahaan, pegawai yang akan dipindahtugaskan tidak berhak meminta lokasi penempatan pemindahan jabatan. Namun, karena adanya "orang dalam" maka semuanya sangat mudah dilakukan. 
Kedua, kebiasaan memanfaatkan celah prosedur. Segala bentuk aktivitas dan kegiatan apapun yang diterapkan tentunya memiliki prosedur yang harus dipatuhi, peraturan yang harus dijalankan dan sistem yang mendukung. Namun apa jadinya jika prosedur-prosedur yang ada dijadikan celah untuk melakukan hal-hal yang memberikan keuntungan salah satu pihak? Inilah yang terjadi di BUMN $X$. Ketika prosedur disalahgunakan dan dimanfaatkan celahnya untuk memberikan keuntungan dan mendukung kepentingan seseorang tanpa memikirkan dampaknya di aspek-aspek yang lain. Ketika prosedur yang seharusnya diterapkan di BUMN X untuk rotasi jabatan memakan waktu dan perlu pertimbangan khusus dari tim assesor namun hal ini kemudian tidak diterapkan merupakan satu kondisi nyata yang terjadi di BUMN $X$. Biasanya, untuk menentukan seseorang layak menempati posisi suatu jabatan, terlebih dulu akan diadakan pelatihan dan penilaian terhadap kemampuan seorang pegawai, namun dengan adanya "orang dalam" sikap saling tolong menolong yang tidak pada tempatnya, seluruh prosedur yang seharusnya dijalankan ini menjadi nihil. Tidak perlu diikuti seluruh prosedurnya, semuanya beres, bisa diatur. Terlebih lagi hal ini didukung oleh kosongnya slot jabatan, contohnya instansi yang kekurangan pegawai dalam menangani pekerjaan karena beberapa pegawai telah pensiun. Tentu keadaan ini menjadi salah satu celah yang bisa dimanfaatkan pegawai untuk menjalankan aksi nepotisme-nya. " $A h$, instansi kita lagi butuh orang. Daripada orang lain yang isi kan mending yang udah kita kenal, bisa diatur itu." Pendapat seperti ini adalah salah satu alasan utama maraknya praktik ini.

Pak Fandi sendiri membenarkan bahwa fraud memang terjadi di instansi ini, bahkan terkadang menyebabkan kerugian berupa penurunan pendapatan bagi instansi tetapi beliau berpendapat hal itu tidak dapat dihindari. Sudah begitu keadaannya. Kondisi ini, membenarkan fenomena iceberg yang peneliti jelaskan di bab kedua dalam penelitian ini, selain memang apa yang tampak tidak sebesar apa yang tersembunyi di dalamnya, kondisi ini juga memberikan pandangan bahwa dari hal-hal kecil berupa kebiasaan-kebiasaan itulah yang akhirnya menjadi penyebab terjadinya fraud. Selanjutnya, kondisi ini juga membenarkan teori fraud star di mana di dalam teori fraud star dijelaskan bahwa faktor yang menjadi pemicu seseorang melakukan fraud adalah integritas. Semakin tinggi integritas seseorang, maka akan semakin kecil kemungkinannya dalam melakukan fraud. Pada penemuan dalam penelitian ini menjelaskan bahwa integritas yang rendah memberikan dampak pada perilaku seseorang untuk melakukan nepotisme yang akhirnya berimplikasi pada fraud. Beberapa hal yang peneliti temukan di sini melalui kebiasaan memanfaatkan celah prosedur, dapat dikatakan bahwa pegawai yang melakukan hal tersebut tidak memiliki integritas dan komitmen sehingga hal ini menjadi salah satu bukti bahwa dalam penelitian yang peneliti lakukan, teori-teori sebelumnya yang dijadikan landasan terbukti adanya.

Ketiga, kebiasaan menyiasati sistem dan birokrasi. Kebiasaan menyiasati sistem dan birokrasi terlihat hampir sama dengan 
kebiasaan memanfaatkan celah prosedur karena kedua hal ini memang sebenarnya berkaitan antara satu dengan yang lain. Jika dalam kebiasaan memanfaatkan celah prosedur dilakukan oleh petinggi instansi atau pejabat-pejabat yang ada di dalam instansi, maka menyiasati sistem dan birokrasi adalah tugas staf-stafnya atau bawahan-bawahan para manager yang memiliki kendali atas sistem dan birokrasi itu sendiri. Kak Yuri mengaku pernah melakukan hal tersebut ketika Pak Yono (manager human capital sebelum Pak Lukito) menjabat di instansi ini. Demi membantu saudaranya, Pak Yono meminta Kak Yuri untuk mengubah data pegawai yang baru 7 bulan menjabat di divisi instalasi jaringan menjadi 2 tahun menjabat agar bisa dipindahkan ke jabatan baru yaitu menjadi asisten manajer di bagian marketing. Berikut merupakan pernyataan langsung dari Kak Yuri;

"Masih baru dek, setahun atau dua tahun lalu itu kejadiannya. Pak Yono minta begitu. Dia kan punya saudara disini, adik istrinya. Katanya sih saudara dia itu kekurangan biaya untuk bayar hutanghutangnya yang masih harus dibayar sampai beberapa tahun kedepan. Pak Yono kasihan, namanya juga saudara. Daripada dibantu kasih uang kan mending dibantu naik jabatan aja, tunjangannya naik, gaji naik, dapat uang transportasi juga. Kan lumayan dia jadi bisa nutupin hutangnya. Hidupnya juga jadi lebih enak. Ya kakak yang menyiasati sistem ini, urusan birokrasi semua diatur Pak Yono. Mana ada yang tanya-tanya. Kalo dipikir itu kan termasuk fraud ya, tapi gimana lagi. Kakak kan juga cuma staf aja disini, anak bawang ibaratnya. Jadi ya harus nurut apa kata atasan."

\section{Budaya "Silap Mata, Limper pun Melayang"}

Seperti yang telah dibahas sebelumnya di dalam bab mengenai budaya semua bisa diatur, yang lebih mengarah kepada sifat manusia sebagai dasar rasionalisasi atas kecenderungan melakukan fraud, maka di dalam bab ini tentang budaya silap mata limper pun melayang yang merupakan istilah dari sedikit saja instansi lengah dalam pengawasan maka, jangankan nilai perusahaan yang materil, lima puluh rupiah pun bahkan bisa hilang. Ini menggambarkan situasi di instansi yang pengawasannya kurang baik sehingga prosedur yang ada seringkali hanya menjadi formalitas, dan budaya ini lebih berfokus pada kepentingan instansi itu sendiri. Di instansi ini prosedurprosedur yang telah dibangun, kebijakankebijakan yang disusun, tidak serta merta seluruhnya dipatuhi oleh setiap lini di instansi. Prosedur yang ada merupakan sebuah formalitas saja, yang tidak perlu diikuti sepenuhnya. Dan hal-hal ini lahir dari kebiasaan-kebiasaan berikut.

Pertama, kebiasaan 'tidak masalah, yang butuh instansi'. Kebutuhan dan kepentingan instansi tentunya menjadi salah satu hal yang harus didahulukan dalam melakukan pekerjaan. Akan tetapi, masalah muncul jika kebutuhan dan kepentingan instansi ini akhirnya disalahgunakan oleh pihak-pihak terkait untuk menutupi nepotisme yang terjadi. Inilah yang menjadi mindset pegawaipegawai di BUMN X. Ketika nepotisme dilakukan, membantu kerabat dan orang lain untuk bisa bekerja ataupun menduduki satu jabatan, yang menjadi tumbalnya adalah 
kebutuhan instansi. Semua kesalahan yang dilakukan, ketidaksesuaian yang dilakukan dilimpahkan kepada kepentingan dan kebutuhan instansi sehingga sangat mudah sekali bagi pegawai ataupun pejabat di BUMN X untuk menutupi dan mengelabui pihak lain dalam menjalankan aksi nepotismenya.

Prosedur memang hanya sebuah formalitas, mau siapa yang bekerja di instansi ini ya silakan, baik melewati prosedur resmi, tidak melewati prosedur resmi juga silakan asalkan punya alasan, punya penopang juga. Apalagi soal naik jabatan, gampang selama memang kuat backing-nya. Toh nanti yang berlagak jujur juga akan terbiasa sendiri dengan budaya yang ada di instansi ini. Kak Yuri contohnya.

"Mau terlalu bersih juga mana ada sih yang bersih di dunia ini dek. Di sinilah baru kakak sadar. Paling kalo mau bersih gak ada begini-begininya ya mending jadi akademisi aja. Susah lah kalo mau mengandalkan pekerjaan kayak gini harus bersih, harus semua-semua jujur. Udah budayanya begini. Kebiasaannya begini. Gimana lagi mau dirubah. Ibarat adek tiap pagi harus sarapan, tiba-tiba mau dirubah jadi gak usah sarapan lagi, pasti sakit perutnya kan? Ya gitu juga di sini. Udah kebiasaan, susah mau diubah. Makanya kita liat aja nanti ujungnya instansi ini gimana. Urusan dosa, atau apalah namanya, orang alim pun juga punya dosa dek."

Kedua, kebiasaan merasa 'aman' karena semua adalah keluarga. Di dalam instansi ini, motto yang dianut adalah "semua adalah keluarga." Hal ini menjadi sangat melekat di setiap diri pegawai yang akhirnya disalahartikan. Semua pegawai bebas melakukan apapun selama hal itu dapat dipertanggungjawabkan dan dilakukan dengan rapi tanpa cacat sedikit pun sehingga walaupun jelas tidak memiliki hubungan keluarga, kekeluargaan di instansi ini sangat lekat sekali. Ada beberapa hal yang tanpa sengaja peneliti mencuri dengar percakapan salah satu pegawai dengan Pak Fandi.

Pegawai X: "Pak, ada ini keponakan saya, baru lulus sarjana dari Universitas Y. IPK nya lumayan lah, bisa gak ya pak kira-kira bantu untuk dia kerja disini? Udah berapa bulan juga dia nganggur. Males ikut rekrutmen instansi kita katanya karena saingan pasti banyak. Kemungkinan lolos juga kecil. Lagian kalo ada keluarga sendiri kan gapapa ya pak? Hehe."

Pak Fandi: "lya, di instansi ini kan semuanya keluarga. Jadi aman-aman aja. Bisa diaturlah itu. Suruh aja keponakanmu bawa CV-nya, tapi ya saya gak bisa janjiin langsung pegawai tetap loh ya. Honorer dulu. Soalnya gak ikut rekrutmen. Kecuali kalo dia ikut rekrutmen, lolos tahap satu aja saya bisa jamin untuk tahap selanjutnya dari tahap 2 sampai tahap 5 semuanya aman."

Percakapan antara Pak Fandi dengan salah satu pegawai yang menyebutkan bahwa siapapun di dalam instansi ini adalah keluarga menjadi memudahkan pegawaipegawai biasa lainnya yang ingin anggota keluarga mereka bisa bekerja dengan mudah di instansi ini. Budaya kekeluargaan yang luar biasa adalah budaya yang sangat baik sebenarnya apalagi di dalam suatu instansi. 
Kecenderungan untuk berkompetisi menjadi semakin kecil, tidak ada yang berusaha menjatuhkan satu sama lain. Malah selalu saling tolong menolong di setiap keadaan. Hanya saja, budaya kekeluargaan yang diterapkan di dalam instansi ini tidak sesuai dengan budaya kekeluargaan yang seharusnya. Kekeluargaan di sini adalah saling melindungi antara satu dengan yang lain namun dalam maksud dan arti yang berbeda. Yaitu menghalalkan cara untuk melakukan nepotisme dan saling melindungi di atas kata nepotisme itu sendiri.

Di dalam instansi ini, kebiasaan merasa aman juga diterapkan pada aktivitas dan kegiatan sehari-hari. Hal ini juga merupakan kepentingan instansi, karena secara prosedur, apabila budaya kekeluargaan ini diterapkan, dan seluruh pegawai merasa aman, maka pekerjaan yang dihasilkan juga akan maksimal. Tapi apabila budaya kekeluargaan dan rasa aman para pegawai di instansi ini tidak diterapkan, maka jangankan pekerjaan yang beres dikerjakan, semua pegawai akan berlomba-lomba bersaing untuk mendapatkan apa yang menjadi kepentingannya. Namun, kembali lagi. Ternyata budaya kekeluargaan yang digadang-gadang ini akhirnya disalahartikan oleh pegawai. Hal ini dijelaskan lebih lanjut oleh Bang Bobi yang merupakan staf keuangan BUMN X;

"Karena kan, kekeluargaan yang menjamin keamanan ini juga kepentingan instansi dek, kebutuhan lah kita bilang. Instansi butuh orang-orang yang menerapkan kekeluargaan, yang punya rasa solidaritas tinggi akhirnya ya gini. Semua berasa keluarga, semua jadi ditolong. Mau keluarganya yang dari negara Arab sana juga ditolong kalo masih punya hubungan kekerabatan sama pegawai disini. Tapi ya gitu, pertolongannya pertolongan untuk kerja, untuk naik jabatan, dan untuk yang lainnya. Hehehe."

Dalam penemuan pada penelitian ini terdapat empat elemen yang tidak dijalankan dengan baik sehingga memicu terjadinya fraud yakni; objektivitas, profesionalitas, meritokrasi, dan materialitas. Pola kebiasaan pegawai di BUMN X cenderung lebih subjektif terhadap keadaan sekitarnya, mengesampingkan profesionalitas karena memiliki kepercayaan yang tinggi terhadap kerabat yang dianggap dapat menempati suatu jabatan tertentu, tidak menerapkan meritokrasi yang merupakan sistem kepantasan dari segi kemampuan untuk menilai apakah seorang pegawai layak menjabat di posisi tertentu atau tidak serta anggapan bahwa hal-hal yang dilakukan tidak bersifat materiil sehingga tidak masalah jika melakukan hal yang memicu terjadinya fraud. Inilah yang menjadi kebiasaankebiasaan yang telah membudaya di lingkungan BUMN $X$ di mana instansi ini sendiri mengadopsi standar Sarbanes Oxley yang mengacu pada sistem barat dalam pengimplementasian operasionalnya. Keadaan ini menggambarkan bahwa standar yang diterapkan jelas tidak sesuai dengan pola kebiasaan pegawai BUMN $\mathrm{X}$ yang sosialis. Jika standar yang digunakan adalah standar yang bersifat liberal, individu yang cenderung sosialisasi akan sangat enggan untuk menerapkan standar tersebut secara sukarela. Penerapan tersebut hanya akan 
selalu ada "di atas kertas" namun tidak benar-benar berjalan pada praktiknya. Dan ketidaksesuaian yang terus menjadi budaya ini, tanpa disadari melahirkan nepotisme yang dapat memicu terjadinya fraud.

\section{SIMPULAN}

Penelitian ini menemukan bahwa pada BUMN X regional Sumatera, budaya-budaya yang menjadi penyebab fraud pada awalnya terletak di komponen sumber daya manusia (SDM) yang merembet luas ke bagian-bagian lainnya. Hal ini membuktikan teori tentang fraud di mana dalam melakukan fraud, seseorang akan merasionalisasi hal tersebut sehingga dengan mudahnya mereka dapat melakukan hal tersebut. Ditambah lagi kepentingan-kepentingan pribadi serta kebutuhan instansi yang menjadi dalih agar hal ini dapat dilakukan. Budaya "cincai-cincai lah" atau semua bisa diatur, jelas sekali sangat kental di instansi ini. Dari kebiasaan menolong yang tidak pada tempatnya, kebiasaan mengandalkan orang dalam, kebiasaan memanfaatkan celah prosedur, kebiasaan menyiasati sistem dan birokrasi. Budaya selanjutnya adalah budaya "Silap mata, limper pun melayang" di mana di instansi ini, pengendalian internal dan pengawasan yang kurang menjadi kesempatan pegawai instansi untuk melangkahi prosedur yang dianggap hanya sebuah formalitas. Hal ini juga berawal dari kebiasaan berpikir "tidak masalah, yang butuh instansi." Untuk menghalalkan pegawai dalam melakukan nepotisme yang berimplikasi pada fraud, rasionalisasi ini digunakan untuk melancarkan perbuatannya. Begitu juga dengan kebiasaan merasa aman karena semua adalah keluarga.
Sekilas terlihat seperti kepentingan pribadi, namun di instansi ini memang diwajibkan semua pegawainya memiliki mindset bahwa "kita adalah keluarga" yang akhirnya disalahartikan untuk saling membantu dalam tindakan yang berujung fraud.

Beberapa keterbatasan di dalam penelitian ini di antaranya adalah, pertama penelitian ini hanya terbatas pada fraud yang terjadi di bagian sumber daya manusia (SDM) karena seluruh masalah sebenarnya berasal dari manusia itu sendiri, yang akhirnya merembet ke hal-hal lainnya. Kedua, topik yang diangkat dalam penelitian merupakan topik yang sangat sensitif, sehingga apapun itu yang merupakan identitas, dan beberapa hal lainnya yang berkaitan dengan informan dan objek penelitian harus disamarkan demi menjaga kerahasiaan serta kesepakatan di awal dalam melakukan penelitian, bahwa identitas apapun tidak boleh diungkapkan.

Bagi peneliti selanjutnya yang ingin membahas lebih detail dan dalam mengenai fenomena fraud di instansi ini, dapat memperluas pembahasannya ke berbagai divisi yang ada di instansi dan akan sangat membantu sekali jika peneliti juga merupakan bagian internal di dalam instansi sehingga akan mempermudah peneliti dalam mengeksplor tindakan-tindakan fraud yang masih terselubung. Kemudian, peneliti selanjutnya juga dapat mengungkap bagaimana fraud yang terjadi di bagian keuangan secara terfokus, apakah sistem canggih yang digunakan oleh instansi benarbenar bisa meminimalisir adanya fraud di bagian keuangan ini, mengingat bahwa beberapa sistem dapat disiasati oleh pegawai. 


\section{DAFTAR PUSTAKA}

Abdallah, A., Maarof, M.A., \& Zainal, A. (2016). Fraud Detection System; A Survey. Journal of Network and Computer Applications, 68, 90-113.

Davis, J.S. \& Pesch, H.L. (2013). Fraud Dynamics and Controls in Organizations. Accounting, Organizations, and Society, 38(6-7), 469-483.

Dinata, R. (2015). Persepsi Auditor atas Tindakan Pencegahan dan Pendeteksian dalam Meminimalisasi Kecurangan Laporan Keuangan Pemerintah Kota Medan Berdasarkan LHP BPK RI Tahun 2013. Penelitian Akuntansi. Universitas Negeri Medan.

Firfiray, S., Cruz, C., Neacsu, I., \& Mejia, L. (2017). Is Nepotism so Bad for Family Firms? A Socioemotional Wealth Approach. Human Resources Management Review, 28(1), 83-97.

Gusti, R. (2016). Ruwatan Warga Agar PT Telkom Tak Korupsi. Diakses dari http://www.rmolsumut.com/read/2016/ 04/21/38499/Ruwatan-Warga-Agar-PTTelkom-Tak-Korupsi-

Indonesian Corruption Watch. (2016). Annual Report. Jakarta. Diakses dari https://antikorupsi.org/id/articles/annualreports.

Ismoyo, B. (2017). Indonesia Kehilangan Rp. 5,8 Triliun Akibat 24 BUMN Rugi di 2017. Diakses dari http://www.bbc.com/ indonesia/indonesia-41107226,

Johnson, P. (1999). Preventing Fraud. Accountancy Ireland, 31(5), 20-21.

Liu, X. (2016). Corruption Culture, and Corporate Misconduct. Journal of Financial Economics, 122(2), 307-327.

Luthans, F. (2011). Organizational Behavior (12 ${ }^{\text {th }}$ Edition). New York: McGraw Hill.

Mardiasmo. (2009). Akuntansi Sektor Publik. Yogyakarta: Andi.
Miller, N. \& Dollard J. (1941). Social Learning and Imitation. New Haven, CT: Yale

Munteanu, V., Copcinschi, L., Luschi, C., \& Laceanu, A. (2016). Internal Audit Determinant Factor in Preventing and Detecting Fraud Related Activity to Public Entities Financial Accounting. Knowledge Horizons Economics, 8(2), 14-21.

Ndraha, T. (2005). Teori Budaya Organisasi. Jakarta: Rineka Cipta.

Othman, R., Aris, N.A., Mardziyah, A., Zainan, N., \& Amin, N. (2015). Fraud Detection and Prevention Methods in the Malaysian Public Sector: Accountants and Internal Auditors Perceptions. Procedia Economics and Finance, 28, 59-67.

Petrascu, D., \& Tieanu, A. (2014). The Role of Internal Audit In Fraud Prevention and Detection. Procedia Economics and Finance, 16, 489-497.

Priantara, D. (2013). Fraud Auditing and Investigation. Jakarta: Mitra Wacana Media.

Schein, E. (1985). Organizational Culture and Leadership. San Fransisco: Jossey Bass.

Schwartz, M. (2013). Developing and Sustaining an Ethical Corporate Culture: The Core Elements. Business Horizons, 56(1), 39-50.

Sekarwulan, N. (2008). Pengaruh Pengendalian Intern Kas Terhadap Tingkat Kecurangan Kas (Survey pada beberapa BUMN di Bandung). Penelitian Akuntansi. Universitas Widyatama.

Supriyono, H. (2017). Mengungkap Modus Fraud di Sektor Pemerintahan. Tesis. Universitas Brawijaya.

Syahrina, D. (2016). Menelisik Budaya Pemicu Fraud : Studi Etnografi Pengelolaan Keuangan Negara. Tesis. Universitas Brawijaya.

Tjandinegara, E. (2017). Keluhan Pelanggan. Diakses

dari 
Jurnal Economia, Volume 14, Nomor 1, April 2018

https://mediakonsumen.com/2017/07/2 7/surat-pembaca/keluhan-pelanggantelkom.

Tylor, E.B. (1971). Primitive Culture: Researches into the Development of Mythology, Philosophy, Religion, Art, and Custom Vol.2. New York: Gordon Press. University Press.
Zamzami, F., Nusa, N.D., \& Timur, R.P. (2015). The Effectiveness of Fraud Prevention and Detection Methods at Universities in Indonesia. International Journal of Economics and Financial Issues, 6(3S), 6669. 